\title{
Turbot (Scophthalmus maximus) vs. VHSV (Viral Hemorrhagic Septicemia Virus): A Review
}

\author{
Patricia Pereiro, Antonio Figueras and Beatriz Novoa* \\ Instituto de Investigaciones Marinas, Consejo Superior de Investigaciones Científicas, Vigo, Spain
}

Turbot (Scophthalmus maximus) is a very valuable fish species both in Europe and China. The culture of this flatfish is well-established but several bacteria, viruses, and parasites can produce mortality or morbidity episodes in turbot farms. Viral Hemorrhagic Septicemia Virus (VHSV) is one of the most threatening pathogens affecting turbot, because neither vaccines nor treatments are commercially available. Although the mortality in the turbot farms is relatively low, when this virus is detected all the stock have to be destroyed. The main goals that need to be improved in order to reduce the incidence of this disease is to know what are the strategies or molecules the host use to fight the virus and, in consequence, try to potentiate this response using different ways. Certain molecules can be selected as potential antiviral treatments because of their high protective effect against VHSV. On the other hand, the use of resistance markers for

OPEN ACCESS

Edited by:

Rubina Sirri,

University of Bologna, Italy

Reviewed by:

Tiziano Verri,

University of Salento, Italy Anna Toffan,

Istituto Zooprofilattico Sperimentale delle Venezie, Italy

*Correspondence: Beatriz Novoa beatriznovoa@iim.csic.es

Specialty section: This article was submitted to Aquatic Physiology, a section of the journal Frontiers in Physiology

Received: 23 March 2016 Accepted: 12 May 2016 Published: 26 May 2016

Citation:

Pereiro P, Figueras A and Novoa B

(2016) Turbot (Scophthalmus maximus) vs. VHSV Niral

Hemorrhagic Septicemia Virus): A

Review. Front. Physiol. 7:192.

doi: 10.3389/fphys.2016.00192 selective breeding is one of the most attractive approaches. This review englobes all the investigation concerning the immune interaction between turbot and VHSV, which until the last years was very scarce, and the knowledge about VHSV-resistance markers in turbot. Nowadays, the availability of abundant transcriptomic information and the recent sequencing of the turbot genome open the door to a more exhaustive and profuse investigation in these areas.

Keywords: turbot, VHSV, disease, immunity, antiviral, transcriptome, resistance, QTLS

\section{TURBOT AQUACULTURE}

Turbot (Scophthalmus maximus) is an economically relevant flatfish species belonging to the family Scophthalmidae (order Pleuronectiformes) widely distributed from Norway to the Mediterranean and the Black Sea (Nielsen, 1986). The first steps in the production of this fish were conducted in Scotland (UK) during the 1970's, but then the turbot aquaculture was quickly expanded to Spain and France (FAO). After numerous technical and biological improvements, their production was also initiated in other European countries (Portugal, Denmark, Germany, Iceland, Ireland, Italy, Norway, and Wales). Nowadays, the culture of this fish is well-established and the complete farm-raising cycle is conducted in land-based aquaculture facilities.

In Europe, turbot aquaculture production was about 11,000 tonnes in 2014, a 38.3\% higher with regard to 2013, being Spain the main European producer [Asociación Empresarial de Productores de Cultivos Marinos (APROMAR), 2015]. Indeed, 7808 tonnes were produced in Spain in 2014. This species, native to Europe, is also cultured in Chile (about 107 tonnes per year) but especially in China, reaching an annual level of 50,000-60,000 tonnes in recent years and being the largest producer of turbot in the world [Food and Agriculture Organization of the United Nations (FAO), 2010]. Currently in Spain only a third of the turbot in the markets comes from fisheries [Asociación Empresarial de Productores de Cultivos Marinos (APROMAR), 2015]. 
Nevertheless, there are still some limitations affecting the culture of this flatfish, such as the low genetic renewal of the breeders and specific diseases which causes mortality and morbidity episodes, with the subsequent economic losses. The development of the turbot aquaculture caused a concomitant increase in pathological conditions affecting the culture of this flatfish. Several pathogens, including bacteria, viruses, and parasites affect the health status of the farmed turbot. Although, today there are effective treatments or vaccines available against a variety of pathogens affecting turbot culture, other diseases, especially those induced by viral agents, have not an easy solution. Neither vaccines nor therapeutic treatments are commercially available for the most of the viral diseases affecting fish.

Viruses are probably the most destructive pathogens encountered in aquaculture and they are a serious concern since no specific chemotherapies are available. To illustrate the impact of fish viruses it can be pointed out that among the 10 notifiable fish diseases (diseases with great social and economic and/or public health repercussion or with present or potential risk for the aquaculture industry) appearing at the 2014 Aquatic Animal Health Code of the OIE (Office International des Epizooties, now the World Organization for Animal Health) (http://www.oie.int), eight are caused by viruses. Viral Hemorrhagic Septicemia Virus (VHSV), a virus affecting S. maximus production, is included in this OIE list.

\section{VIRAL HEMORRHAGIC SEPTICEMIA VIRUS (VHSV)}

\section{Taxonomy, Structure, Genotypes, and Geographical Distribution}

VHSV is a fish pathogen belonging to the genus Novirhabdovirus, within the family Rhabdoviridae (Walker et al., 2000; Tordo et al., 2005). Rhabdoviruses are bulletshaped, 170-180 $\mathrm{nm}$ in length, and 60-70 $\mathrm{nm}$ in width (Elsayed et al., 2006), enveloped viruses with a simple negative-sense, single-stranded RNA (ssRNA) genome of $\sim 11 \mathrm{~kb}$ (Schutze et al., 1999). The typical rhabdoviral genome encodes five basic structural proteins: nucleoprotein $(\mathrm{N})$, polymerase-associated phosphoprotein $(P)$, matrix protein $(M)$, glycoprotein $(G)$, and large RNA-dependent RNA polymerase (L). Members of the genus Novirhabdovirus are distinguished by the presence a sixth gene located in the genome between the $\mathrm{G}$ and the $\mathrm{L}$ genes, encoding a non-structural or non-virion (NV) protein (Kurath and Leong, 1985; Schutze et al., 1999), which is implicated in the pathogenesis (Ammayappan and Vakharia, 2011; Choi et al., 2011; Figure 1A). All rhabdoviruses possess non-coding $3^{\prime}$ leader and $5^{\prime}$ trailer sequences.

Structurally, all rhabdoviruses have two major structural components: a helical ribonucleoprotein core (RNP) and a surrounding envelope (Figure 1B). In the RNP, genomic RNA is tightly encased by the nucleoprotein. The phosphoprotein and the large protein (L-protein or polymerase) are also associated with the RNP. The glycoprotein (G) forms trimeric spikes which are tightly inserted into the lipid bilayer (typical of enveloped viruses and derived from portions of the host cell membranes).
Under and associated to the membrane by hydrophobic and electrostatic interactions is a layer formed by the matrix protein (M), which condenses the RNP. Moreover, M protein is also associated with the lipid bilayer and the glycoprotein, forming a link between the ribonucleocapsid and glycoproteins in the viral envelope (Assenberg et al., 2010).

Phylogenetic analysis allowed the identification of four geographically distinct major VHSV-genogroups based on $\mathrm{N}$ - and G-gene nucleotide variation (Snow et al., 1999, 2004; Einer-Jensen et al., 2004). Genotype I is composed of rainbow trout freshwater isolates (Genotype Ia) and marine isolates from the Baltic Sea ( $\mathrm{Ib}$ ) closely related to those belonging to Ia (Snow et al., 1999). European marine strains are divided into two groups: Baltic Sea isolates (Genotype II), and isolates from the North Sea and European Atlantic (Genotype III). Finally, Genotype IV is composed by North America strains. Additionally, Genotype I and IV can also be divided into five (Ia-Ie) and three (IVa-IVc) subtypes based on their reactivity to different monoclonal antibodies (Ito et al., 2012). At this regard, genotypes Ia and II revealed low mortality in experimentally infected turbot, while Ib showed an intermediate effect and the highest mortality levels were obtained in turbot infected with isolates from the Genotype III (Snow et al., 2005). Interestingly, it was observed that the differences in virulence among phylogenetically distinct VHSV isolates are not explained by the variability of the surface glycoprotein $G$ or the non-virion $(\mathrm{NV})$ protein (Einer-Jensen et al., 2014). The outbreaks detected in turbot farms were mainly caused by the UK-860/94 strain (Genotype III). Indeed, this strain was isolated from the outbreak at the Gigha turbot farm (Scotland; Ross et al., 1994).

\section{Fish Species Affected by VHSV, Clinical Signs, and Problems in Turbot Farms}

This etiological agent causes an important viral disease affecting rainbow trout Oncorhyncus mykiss and other salmonids (Castric and de Kinkelin, 1980; Hørlyck et al., 1984; Wolf, 1988) but VHSV outbreaks have been detected in other farmed fish species such as turbot (Schlotfeldt et al., 1991; Ross et al., 1994). Indeed, since the last 1970's, VHSV has been isolated from at least 50 species of marine and freshwater fish (Skall et al., 2005). It was also observed that some VHSV strains are able to infect several host species and sporadically cross species barriers (Schönherz et al., 2013).

Diseased fish may display non-specific clinical signs in the early stages of infection, including rapid onset of mortality (which can reach up to $100 \%$ in fry), lethargy, darkening of the skin, exophthalmia, anemia (pale gills), hemorrhages at the base of the fins, gills, mouth, eyes, and skin, a distended abdomen due to edema in the peritoneal cavity, and severe abnormal swimming behavior. Some of the clinical signs observed after the intraperitoneal injection of the VHSV strain UK-860/94 in juvenile turbot are shown in Figure 2. Regarding to the latency of the virus, there are contradictory studies, some of them suggesting that VHSV is not able to remain in surviving fish (Snow and Smail, 1999; Chico et al., 2006; Duesund et al., 2010), whereas other investigations indicate the contrary (Schönherz 


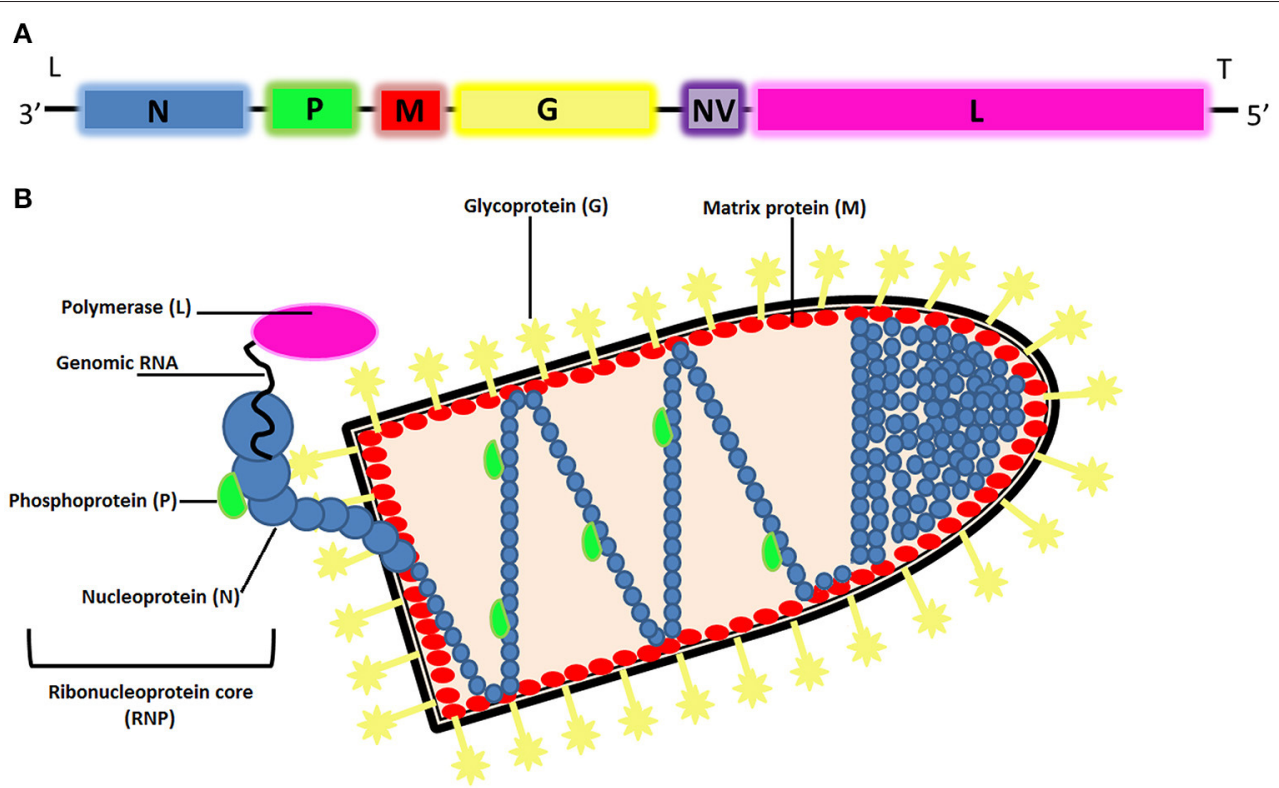

FIGURE 1 | (A) Organization of the VHSV genome. The gene order of VHSV is $3^{\prime}$-leader-N-P-M-G-NV-L-trailer-5' . (B) Schematic representation of the morphology and structural components of rhabdoviruses.

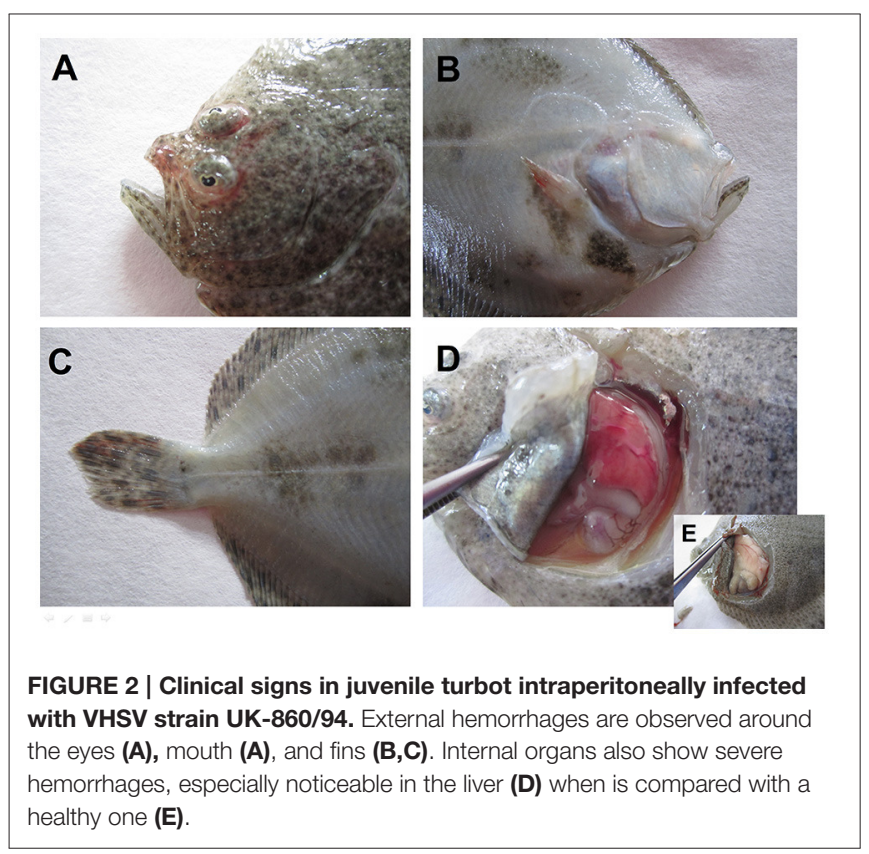

et al., 2013). Nevertheless, the persistence of VHSV in the host is probably conditioned by the specificity/virulence of the VHSV genotype to the fish species and also by the lapse of time after the exposition to the virus, among other conditions. On the other hand, the different sensibility of the detection methods could provide opposite results.

In recent years, due to the intensive farming conditions, disease outbreaks caused by sea water viral pathogens have frequently become severe problems faced by turbot industries worldwide. VHS outbreaks in turbot facilities were reported from a research institution in Germany in 1991 (Schlotfeldt et al., 1991), and turbot farms in Scotland in 1994 (Ross et al., 1994), and Ireland in 1997 (Skall et al., 2005). Although no official data reporting the incidence of VHSV in European turbot farms during the last two decades are available, we cannot discard the presence of this virus in the facilities and even the possibility that VHSV could be the causative agent of punctual mortality episodes. Unfortunately, when private economic interests are implicated, the transparency is not as good as could be expected.

In the case of the first declared VHSV outbreak in a turbot farm (Ross et al., 1994), although the mortality rate was relatively low (6\%), all the stock (about 14 tonnes) was collected and sacrificed as a part of a contingency plan (Hastein et al., 1999). Nowadays the European council directive 2006/88/EC lists the VHS as a non-exotic disease and, as consequence, when VHSV is detected in a fish farm the clinically healthy animals are allowed to continue growing until reaching the commercial size if no disease outbreak appears. Nevertheless, severe control measures have to be taken when a VHSV outbreak occurs in order to avoid the spread of the disease and to eradicate the virus from the facilities.

\section{Control and Prevention}

Due to the absence of effective antiviral treatments, prevention is the critical point in the eradication of this disease. In addition to the biosecurity measures that should be taken in order to prevent the entry/spread of the virus, some immune-related aspects are the key points in order to reduce the impact of viral diseases. The main prophylactic measures include probiotics, immunostimulation, and vaccination. The use of probiotics and immunostimulants in aquaculture, mainly provided through 
specific dietary manipulation, could help to enhance the innate immune system of fish (Olafsen, 2001; Magnadottir, 2010). Although, these substances were mainly tested against pathogen bacteria, some studies revealed their positive effect against viral diseases in teleost fish (Jensen et al., 2002; Jorgensen et al., 2003; Lockhart et al., 2004; Fernandez-Trujillo et al., 2008; Das et al., 2009; Kim et al., 2009; Son et al., 2009; Chiu et al., 2010; Harikrishnan et al., 2010; Liu et al., 2012). It was observed that the administration of DNA CpG motifs (plasmid pMCV1.4) in turbot was able to reduce the mortality caused by a VHSV challenge even 1 month after the immunostimulation (Pereiro et al., 2012c), and microarray analysis showed that some gene modulation remained active in these fish (Pereiro et al., 2014a).

No vaccines are commercially available for VHSV. For more than 30 years, an increased effort was performed in order to produce an efficient, safe, and cost-effective vaccine against VHSV using subunits or single viral proteins as well as killed or attenuated viruses (de Kinkelin et al., 1980, 1995; Bernard et al., 1983; Leong and Fryer, 1993; Lecocq-Xhonneux et al., 1994; Adelmann et al., 2008). Although, some of these vaccines had induced good protection levels in laboratory conditions, sometimes they can be unsafe for field use, its production might be very expensive or high doses may be required. Deoxyribonucleic acid (DNA) vaccination is based on the administration of a plasmid DNA vector containing the gene encoding a specific antigen. This technology is a powerful tool for the design of effective vaccines against fish pathogens. It has become clear that one of the most efficient methods for induction of a protective immune response under experimental conditions in rainbow trout against VHS and other Rhabdoviruses is DNA vaccination, being vaccines encoding viral membrane glycoproteins remarkably efficacious (Anderson et al., 1996; Winton, 1997; Lorenzen et al., 1998, 2000; LaPatra et al., 2001). Rhabdoviruses possess a surface glycoprotein (G protein) that acts as the target of virus neutralizing antibodies (Lorenzen et al., 1990) and the more successful DNA vaccines against these viruses are based on the G glycoprotein gene under the control of the cytomegalovirus promoter (CMV). Intramuscular administration of micrograms amounts of plasmid is enough for the expression of the viral G glycoprotein on the surface of muscular cells and this is the way to trigger the immune response (Lorenzen et al., 2005; Lorenzen and LaPatra, 2005). In turbot, a DNA vaccine encoding the G glycoprotein from VHSV UK-860/94 strain was tested in juvenile turbot, and highly promising results were obtained, with a relative percentage of survival (RPS) over 80\% (Pereiro et al., 2012c). Moreover, the transcriptome analysis after the administration of this vaccine showed an activation of the main immune-pathway in a similar way to that induced by VHSV (Pereiro et al., 2014a). One month after vaccination, the transcriptome profile was totally different among vaccinated and non-vaccinated individuals, showing this last group an uncontrolled and intense innate immune response (Pereiro et al., 2014a). These results reflect the potential of the DNA vaccination strategies in fish aquaculture. Nevertheless, fish immunization by an antigen-encoding DNA vaccine was only approved for commercial sale in Canada against IHNV (also a Novirhabdovirus) in farmed salmon (Evensen and Leong, 2013).
At present there has not been approved any DNA vaccine to be used in aquaculture in Europe.

Another way to prevent, or al lest reduce, the prevalence of one disease is the genetic improvement. Marker-assisted selection (MAS) in fish breeding schemes has become a very promising strategy for obtaining individuals with a certain traits of interest. In fish aquaculture these traits are specially focused on growth, sex determination, and resistance to diseases. Nowadays the majority of MAS work uses DNA-based marker, especially after the proliferation of the genome-wide studies due to the lower cost of the genome sequencing strategies. Nevertheless, this markers can be also morphological, biochemical, or cytological. Some of these aspects will be discussed below.

\section{ANTIVIRAL IMMUNE RESPONSE IN TURBOT}

\section{General Considerations}

In spite of the relevance of turbot culture and the associated pathological process, until a few years ago the knowledge about its immune system was still very fragmentary and little was known about host-pathogen interactions. The pathways implicated in the response against pathogens remained incomplete in turbot and the understanding of how those defense mechanisms act is a relevant factor in order to enhance resistance of cultured fish to diseases. Fortunately, during the last years a great increase in the knowledge of the immune-relevant genes in S. maximus has been achieved due to the next-generation sequencing (NGS) strategies (Pereiro et al., 2012a; Ribas et al., 2013; Ma et al., 2016). Indeed, in a 454-pyrosequencing conducted using tissues from turbot inoculated with viral stimuli, including VHSV, the main reference immune pathways of vertebrates (complement pathway, Toll-like receptor signaling pathway, B- and T-cell receptor signaling pathways, and apoptosis) were found to be almost completed with sequences for the genes implicated therein (Pereiro et al., 2012a). But the ultimate step was recently achieved with the publication of the whole genome of turbot (Figueras et al., 2016). With all this information, intensive transcriptome analysis and/or identification of candidate genes implicated in the resistance against a certain disease can be conducted.

\section{Transcriptome Analysis of Turbot Against VHSV}

Several immune genes have been found to be modulated in turbot after VHSV challenge when they were individually analyzed. Nevertheless, some microarray analysis works were conducted, revealing larger and very valuable transcriptome information (Díaz-Rosales et al., 2012; Pereiro et al., 2014b).

Humoral growth inhibitors can act inhibiting the proliferation of the microorganisms by restricting the availability of some elements essential for their proliferation or interfering with their metabolism. Proteins implicated in iron homeostasis, such as transferrin, hepcidin, or hemopexin, acts as a growth inhibitor of bacteria by chelating available iron essential for the bacterial maintenance (Hugman, 2006; Tolosano et al., 2010; Gkouvatsos et al., 2012) or for viral replication (Drakesmith and Prentice, 
2008). Two hepcidin genes were described in some fish species, including S. maximus (Pereiro et al., 2012b). Both isoforms were modulated after VHSV infection, with down-regulations at short times post-challenge and over-expressions after 24 and $72 \mathrm{~h}$. One of them (hepcidin-2) seems not to be implicated in the iron homeostasis, although hepcidins are also related with other immune functions, being a powerful antimicrobial peptide and an immunomodulator in vertebrates (Krause et al., 2000; De Domenico et al., 2010; Rajanbabu et al., 2010). It is interesting to highlight that in a previous work conducted by Díaz-Rosales et al. (2012) using microarrays to compare two low mortality families and two high mortality families of turbot against VHSV, they found that hepcidin-2 (annotated as antimicrobial peptide precursor) was significantly higher expressed in naïve condition in those families showing low mortality rate and therefore, this gene could be directly related with the resistance to the virus. On the other hand, both hepcidin genes were significantly lower expressed at $24 \mathrm{~h}$ post-challenge in resistant families compared to susceptible families (Díaz-Rosales et al., 2012). This was also observed in the case of one hemopexin member. Some studies in mice showed that hemopexin, in addition to its role in iron homeostasis, it is also an inflammatory regulator (Liang et al., 2009; Bakker et al., 2010; Spiller et al., 2011). Teleost possess two hemopexin (or warm-acclimation temperature protein-wap65) genes, which were also identified in turbot (Díaz-Rosales et al., 2014). Interestingly, both genes were down-regulated in response to a VHSV challenge; this was probably due to the antiinflammatory effect of these proteins, which was observed for the first time in teleost by Díaz-Rosales et al. (2014). Indeed, turbot families showing higher resistance to the virus presented a higher inhibition of wap65-2 expression after the viral challenge (Díaz-Rosales et al., 2012), probably because its role as antiinflammatory protein diminish the antiviral response.

In this microarray comparing families of turbot with different susceptibilities to VHSV other gene resulted very interesting, the nk-lysin. This gene was found to be more expressed in low mortality families in basal conditions (Díaz-Rosales et al., 2012). Nk-lysin (or granulysin in humans) is an antimicrobial peptide produced by NK-cells and cytotoxic T-lymphocytes and stored in cytolytic granules together with perforin and granzymes (Andersson et al., 1995). The perforin-granzyme pathway induce apoptosis of target cells when both molecules are released after the recognition of antigens via major histocompatibility complex (MHC) class I presentation (Trapani and Smyth, 2002). Nevertheless, the function of Nk-lysin in this defensive mechanism is not clear. This peptide was isolated from several vertebrate species and showed a broad antibacterial spectrum (Andersson et al., 1995; Stenger et al., 1998; Lee et al., 2014; Zhang et al., 2014), but its implication in the antiviral response remains to be elucidated. Only a few works were published relating teleost Nk-lysin and viral diseases, but mainly based in its gene induction after infection (Zhang et al., 2013; Pereiro et al., 2015). Zhang et al. (2013) characterized one $n k$-lysin gene in other flatfish, tongue sole (Cynoglossus semilaevis), and their results revealed that the intramuscular (i.m.) injection of an expression plasmid encoding this peptide was able to reduce the proliferation of the megalocytivirus in kidney and spleen, as well as to modulate several immune genes, but protection results were not provided. After that, the same authors used a synthetic peptide derived from the tongue sole Nk-lysin and observed that the intraperitoneal (i.p.) injection of this molecule also had an effect in megalocytivirus replication and in the modulation of some immune-related genes (Zhang et al., 2014). As was exposed at the 13th Congress of the International Society of Developmental and Comparative Immunology (ISDCI), some experiment conducted in our laboratory confirmed the link between turbot Nk-lysin and the higher resistance to VHSV (Smith et al., 2016). This relationship is still under investigation, but Nk-lysin could be a promising resistance marker for selective breeding.

Other growth inhibitors are some of the numerous genes induced by type I interferon (IFN), this is interferon-stimulated genes (ISGs), which can reduce the viral proliferation in the host using different blocking mechanisms or strategies (Sadler and Williams, 2008; Varela et al., 2014a). For that reason, the IFN system is considered the main antiviral immune process in vertebrates. The first characterizations of type I IFNs in teleost were conducted in 2003 for zebrafish (Altmann et al., 2003), Atlantic salmon (Robertsen et al., 2003) and pufferfish (Lutfalla et al., 2003) and since that, type I IFNs have been identified in several fish species (Zou and Secombes, 2011). Teleost possess multiple copies of IFN genes in the genome which can present different immune properties, suggesting complementary or specialized roles (Zou et al., 2007; Aggad et al., 2009; LópezMuñoz et al., 2009). Two type I IFNs (ifn1 and ifn2) were recently characterized in S. maximus and, as was expected, a different action mechanism was observed (Pereiro et al., 2014a). Whereas, the injection of an expression plasmid encoding if $n 1$ was able to significantly reduce the mortality rate of turbot against VHSV by diminishing the viral replication, ifn2 did not show any protective ability against the virus (Pereiro et al., 2014a). Gene expression analysis revealed that only if 1 induced the expression of ISGs, whereas the activity of ifn2 was more restricted to an immunomodulatory function (Pereiro et al., 2014a). Therefore, ifn 1 could serve as a good antiviral treatment of VHSV-infected individuals, helping to eradicate an outbreak in a turbot farm.

The most exhaustive analysis of the immune response in turbot after VHSV challenge was conducted using a microarray enriched in antiviral sequences (Pereiro et al., 2014b). This microarray was used for analyzing both the gene modulation after the administration of a DNA vaccine specific for VHSV and the transcriptome profiles after VHSV challenge in vaccinated and non-vaccinated fish. As was mentioned above, the vaccine encoding the $\mathrm{G}$ glycoprotein induced a very similar response to that produced by the virus itself; this is high activation of the main immune pathways (toll-like receptor signaling pathway, IFN system, apoptosis, death induced by cytotoxic cells, MHCI antigen presentation process, etc.). All these results could provide valuable information for further investigations about the host-pathogen interaction. It is interesting to highlight, among other remarkable modulations, that TLRs with a typical role in bacterial component detection ( $t \operatorname{lr} 5$ and $t \operatorname{lr} 6)$ were found to be strongly overexpressed after VHSV infection, and this could suggest a novel role of these receptors in the recognition of 
viral components (Pereiro et al., 2014b). The coagulation and complement cascades, which are intimately related, were also affected by the virus administration. VHSV is a hemorrhagic virus causing widespread hemorrhages in fish tissues, which induces inflammation and the modulation of pro-coagulant and anti-coagulants factors (Pereiro et al., 2014b). The complement system, composed of more than 35 proteins, is organized into a cascade that starts with the identification of pathogenic surfaces and finally produces the targeted lysis of the pathogen through the membrane attack complex (MAC; Dunkelberger and Song, 2010). Additionally, the activation of this system also induces the generation of proinflammatory mediators and opsonization of the pathogen surface (Dunkelberger and Song, 2010). The central component of the complement system is the component $\mathrm{C} 3$, which is proteolytically activated through the classical (through antibody binding), lectins or alternative pathways (in both cases an antibody independent activation). VHSV challenge increased the expression of the majority of the analyzed genes but, interestingly, a significant reduction in the transcription of complement C1q subcomponent subunit $C$ was observed, and also a more discrete inhibition in the level of mannanan-binding lectin serine protease-2 (Pereiro et al., 2014b). This probably indicates a prioritization of the alternative pathway at short times after VHSV infection. Indeed, the transcription profile after infection in vaccinated individual (presenting specific antiVHSV antibodies) showed an up-regulation of both genes, the first one forming part of the $\mathrm{C} 1$ complex of the classical pathway of the complement, and the second one implicated in the lectin pathway.

It is interesting to highlight that, besides the potential implication of these immune-related genes in the defense mechanisms against VHSV, numerous genes with an unknown function or a well-described role in other biological or molecular processes not directly related to the immunity, were also modulated after VHSV challenge (Díaz-Rosales et al., 2012; Pereiro et al., 2014b). This opens the door to further lines of investigation, in which new antiviral genes could be identified.

\section{Effect of VHSV in Immune Cells}

Macrophages are one of the main immune cells acting against viral infections (Mogensen, 1979). Their ability to phagocyte, to produce substances highly toxic for microorganisms as reactive oxygen species (respiratory burst) and nitric oxide (NO), and the production and release of numerous molecules implicated in the antiviral defense, are the main mechanisms used by this cell type to combat viruses (Murray and Wynn, 2011).

Almost 20 years ago it was determined that VHSV was able to infect and replicate in turbot head kidney macrophages and blood leukocytes primary cultures both from turbot (S. maximus) and rainbow trout (O. mykiss), although no cytopathic effect was observed and the viral titers were lower than those obtained in the fish cell lines (Tafalla et al., 1998). In these in vitro assays, the respiratory burst activity was measured at several days post-infection, but no significant differences were observed comparing with the control groups (Tafalla et al., 1998). On the other hand, an increase of nitric oxide (NO) production was found in turbot kidney macrophages after VHSV challenge, and an exogenous supplementation of $\mathrm{NO}$ had an antiviral effect on VHSV, significantly inhibiting its replication (Tafalla et al., 1999). Moreover, other in vitro assays conducted in turbot macrophages revealed that VHSV was able to significantly reduce the production of NO induced by tumor necrosis factor $\alpha$ (TNFa) and macrophage-activating factor (MAF; Tafalla et al., 2001). When in vivo VHSV infections where conducted, increases in the macrophage respiratory burst were observed, although the production of NO was not found to be affected (Tafalla et al., 2001). Even the administration of sera from VHSV-infected turbot was able to significantly induce macrophage respiratory burst in vitro (Tafalla et al., 2001).

Little is known about the interaction between host cells and VHSV. A recent publication revealed that the spring viremia of carp virus (SVCV), which is also a Rhabdovirus, is not only able to infect zebrafish (Danio rerio) macrophages in vivo, but these are, at least during the first stages of infection, its target cells (Varela et al., 2014b). During the first hours of infection in zebrafish larvae, the number of macrophages is substantially reduced due to a process of cell death, more specifically through virus-induced pyroptosis of macrophages (Varela et al., 2014b). Probably this process is also occurring in turbot after VHSV challenge. Indeed, microarray analysis revealed a reduction in the expression level of the macrophage receptor with collagenous domain (marco) and the macrophage mannose receptor 1 ( $m r c 1)$, two phagocyte receptor molecules that recognize bacterial components, after VHSV challenge in head kidney samples (Pereiro et al., 2014b). Moreover, macrophage colony-stimulating factor 1 (csfl) and precursor of second macrophage colony stimulating factor (csf1-2), implicated in the macrophage proliferation and differentiation, were also down-regulated (Pereiro et al., 2014b); this was also observed in the case of interleukin-18 (il18), a pro-inflammatory cytokine mainly produced in macrophages and typically highly expressed after viral stimuli (Boraschi and Dinarello, 2006). On the contrary, the cell marker associated to dendritic cells, cd83, was strongly overexpressed in response to VHSV (Pereiro et al., 2014b). This dendritic cell marker can also be expressed on the surface of macrophages (Zhou and Tedder, 1996) and neutrophils (Iking-Konert et al., 2002) under certain inflammatory conditions, and as consequence they evolve into functionally mature CD83+ dendritic cells. The reduction in the expression of the genes associated to macrophages after VHSV challenge could let us think in three hypotheses: the destruction of macrophages by VHSV as occurs in zebrafish with SVCV, the reduction of the number of these cells as a defense mechanisms for avoiding the fast replication of this virus in macrophages, or the transformation of the macrophages into functional dendritic cells. More investigations will be needed in order to clarify this question. Regarding to other immune cells, a slight upregulation of cytotoxic T-cell markers was observed in these first stages of infection, whereas several T-cell receptor (TCR) chain regions and B-cell receptor (BCR) associated proteins were down-regulated (Pereiro et al., 2014b).

\section{Antibodies Production}

The presence of specific antibodies against the G glycoprotein in turbot sera was observed 1 month after the administration 
of a highly effective DNA vaccine encoding this viral protein (pMCV1.4-G 860 ), whereas no specific antibodies were detected in the sera from control turbot (PBS or pMCV1.4-injected fish; Pereiro et al., 2012c). This was determined through an enzymelinked immunosorbent assay (ELISA) using a synthetic peptide from the glycoprotein of the VHSV 07.71 as antigen (Chico et al., 2010), and a monoclonal antibody to turbot IgM (Estevez et al., 1994). Moreover, these antibodies showed neutralizing activity against the virus (Pereiro et al., 2012c). The production of specific and neutralizing antibodies against VHSV was also largely observed in rainbow trout (O. mykiss) after VHSV challenge or immunization using viral proteins or DNA vaccines (Lorenzen et al., 1993; Fregeneda-Grandes and Olesen, 2007; Martinez-Lopez et al., 2013).

\section{MARKER-ASSISTED SELECTION (MAS)}

In aquaculture industry, there are mainly two desirable traits to improve production: growth and resistance to diseases. Nowadays, the MAS of productive traits is mainly based in DNA markers, which can be used to detect allelic variation in the genes underlying a certain trait (Collard et al., 2005). Therefore, the selection is not based on the trait itself, but on the marker linked to it. In this way, the resistance to fish diseases could be improved by using DNA markers to assist in turbot breeding, and this consists in the selection of allelic variations that are linked with the resistance to diseases. The traits are usually controlled by several genes and are known as quantitative traits (Collard et al., 2005). The quantitative trait loci (QTLs) are those regions of the genome containing genes related with a quantitative trait, and the construction of physical linkage maps makes possible to identify these chromosomal regions (Mohan et al., 1997). The marker used for selection is associated in a high frequency with the QTL of interest due to the proximity on the chromosome and therefore they should co-segregate (genetic linkage; Mohan et al., 1997).

Numerous QTLs associated with the resistance and to VHSV have been identified in S. maximus (Rodríguez-Ramilo et al., 2014). Previously to this, QTL analysis were also studied to identify those regions associated with the resistance to the bacteria Aeromonas salmonicida (Rodríguez-Ramilo et al., 2011) and the parasite Philasterides dicentrarchi (Rodríguez-Ramilo et al., 2013). The existence of an accurate linkage map in turbot (Bouza et al., 2007) was crucial in the detection of these QTLs. Some QTLs were found to be related with the resistance to more than one pathogen (Rodríguez-Ramilo et al., 2014), which is very interesting for designing selective programs. Until the sequencing of the turbot genome (Figueras et al., 2016), the identification of candidate genes associated to the genetic markers was mainly based on comparative mapping

\section{REFERENCES}

Adelmann, M., Köllner, B. K., Bergmann, S. M., Fischer, U., Lange, B., Weitschies, W., et al. (2008). Development of an oral vaccine for immunisation of rainbow between the turbot genetic map and the genome of model teleost species by analyzing syntenic areas (Rodríguez-Ramilo et al., 2014). At the present time, the whole genome sequencing of turbot has led to identify, in a reliable and robust manner, numerous candidate genes associated with the resistance to VHSV (Figueras et al., 2016). The genetic markers were located on the genome and gene mining analysis around the QTLs was conducted using a $\pm 1 \mathrm{Mb}$ window and, among the more than 200 candidate genes identified for VHSV, some of the most remarkable finding were numerous genes implicated in T-cell activity, blood coagulation cascade (probably due to the hemorrhagic activity of this virus), and genes related to iron homeostasis and scavenging (like some transferrin-related genes and hepcidin; Figueras et al., 2016). As was mentioned above, hepcidin genes were previously associated with resistance to VHSV in turbot families using microarray analysis (Díaz-Rosales et al., 2012). With all this new information available for the researches, the knowledge about the genes implicated in the defense against this viral disease will be probably expanded in the next years.

\section{CONCLUSIONS}

In summary, this review tried to comprise all the information available about the immune interaction between $S$. maximus and VHSV, which has not been extensively studied. Hitherto this viral disease is still a serious threat in the turbot farms due to the absence of vaccines or effective commercial treatments. A thorough knowledge of the host-pathogen interaction as well as the identification of those molecules directly implicated in the defense against VHSV are the key points that need to be addressed in order to reduce the prevalence of this disease. Nowadays, both the identification of potential treatments based in self-molecules from turbot and the genetic improvement of the breeders are the main strategies under investigation.

\section{AUTHOR CONTRIBUTIONS}

$\mathrm{PP}, \mathrm{AF}$, and $\mathrm{BN}$ have conceived, drafted, and approved the final version of this review.

\section{FUNDING}

This research in our group is funded by projects AGL201451773-C3-2-R from Ministerio de Economía y Competitividad, the European project PARAFISHCONTROL (634429), and the "Proyecto Intramural Especial, PIE" (201230E057) from Agencia Estatal Consejo Superior de Investigaciones Científicas (CSIC). trout (Oncorhynchus mykiss) against viral haemorrhagic septicaemia. Vaccine 26, 837-844. doi: 10.1016/j.vaccine.2007.11.065

Aggad, D., Mazel, M., Boudinot, P., Mogensen, K. E., Hamming, O. J., Hartmann, R., et al. (2009). The two groups of zebrafish virus-induced interferons signal via 
distinct receptors with specific and shared chains. J. Immunol. 183, 3924-3931. doi: 10.4049/jimmunol.0901495

Altmann, S. M., Mellon, M. T., Distel, D. L., and Kim, C. H. (2003). Molecular and functional analysis of an interferon gene from the zebrafish, Danio rerio. J. Virol. 77, 1992-2002. doi: 10.1128/JVI.77.3.19922002.2003

Ammayappan, A., and Vakharia, V. N. (2011). Nonvirion protein of novirhabdovirus suppresses apoptosis at the early stage of virus infection. J. Virol. 85, 8393-8402. doi: 10.1128/JVI.00597-11

Anderson, E. D., Mourich, D. V., Fahrenkrug, S. C., LaPatra, S., Shepherd, J., and Leong, J. A. (1996). Genetic immunization of rainbow trout (Oncorhynchus mykiss) against infectious hematopoietic necrosis virus. Mol. Mar. Biol. Biotechnol. 5, 114-122.

Andersson, M., Gunne, H., Agerberth, B., Boman, A., Bergman, T., Sillard, R., et al. (1995). NK-lysin, a novel effector peptide of cytotoxic T and NK cells. Structure and cDNA cloning of the porcine form, induction by interleukin 2 , antibacterial and antitumour activity. EMBO J. 14, 1615-1625.

Assenberg, R., Delmas, O., Morin, B., Graham, S. C., De Lamballerie, X., Laubert, C., et al. (2010). Genomics and structure/function studies of Rhabdoviridae proteins involved in replication and transcription. Antiviral Res. 87, 149-161. doi: 10.1016/j.antiviral.2010.02.322

Asociación Empresarial de Productores de Cultivos Marinos (APROMAR) (2015). La Acuicultura en España. Cádiz.

Bakker, W. W., Melgert, B. N., and Faas, M. M. (2010). Hemopexin: antiinflammatory, pro-inflammatory, or both? J. Leukoc. Biol. 87, 1-2. doi: 10.1189/jlb.0809560

Bernard, J., de Kinkelin, P., and Bearzotti-Le Berre, M. (1983). Viral hemorrhagic septicemia of rainbow trout: relation between the $\mathrm{G}$ polypeptide and antibody production in protection of the fish after infection with the F25 attenuated variant. Infect. Immun. 39, 7-14.

Boraschi, D., and Dinarello, C. A. (2006). IL-18 in autoimmunity: review. Eur. Cytokine Netw. 17, 224-252. doi: 10.1684/ecn.2006.0047

Bouza, C., Hermida, M., Pardo, B. G., Fernández, C., Castro, J., Fortes, G. G., et al. (2007). A microsatellite genetic map in the turbot (Scophthalmus maximus). Genetics 177, 2457-2467. doi: 10.1534/genetics.107.075416

Castric, J., and de Kinkelin, P. (1980). Occurrence of viral haemorrhagic septicaemia in rainbow trout Salmo gairdneri Richardson reared in sea water. J. Fish Dis. 3, 21-27. doi: 10.1111/j.1365-2761.1980.tb00180.x

Chico, V., Gomez, N., Estepa, A., and Perez, L. (2006). Rapid detection and quantitation of viral hemorrhagic septicemia virus in experimentally challenged rainbow trout by real-time RT-PCR. J. Virol. Methods 132, 154-159. doi: 10.1016/j.jviromet.2005.10.005

Chico, V., Martinez-Lopez, A., Ortega-Villaizan, M., Falco, A., Perez, L., Coll, J. M., et al. (2010). Pepscan mapping of viral hemorrhagic septicemia virus glycoprotein $\mathrm{G}$ major lineal determinants implicated in triggering host cell antiviral responses mediated by type I interferon. J. Virol. 84, 7140-7150. doi: 10.1128/JVI.00023-10

Chiu, C. H., Cheng, C. H., Gua, W. R., Guu, Y. K., and Cheng, W. (2010). Dietary administration of the probiotic, Saccharomyces cerevisiae P13, enhanced the growth, innate immune responses, and disease resistance of the grouper, Epinephelus coioides. Fish Shellfish Immunol. 29, 1053-1059. doi: 10.1016/j.fsi.2010.08.019

Choi, M. K., Moon, C. H., Ko, M. S., Lee, U. H., Cho, W. J., Cha, S. J., et al. (2011). A nuclear localization of the infectious haematopoietic necrosis virus NV protein is necessary for optimal viral growth. PLOS ONE 6:e22362. doi: 10.1371/journal.pone.0022362

Collard, B. C. Y., Jahufer, M. Z. Z., Brouwer, J. B., and Pang, E. C. K. (2005). An introduction to markers, quantitative trait loci (QTL) mapping and markerassisted selection for crop improvement: the basic concepts. Euphytica 142, 169-196. doi: 10.1007/s10681-005-1681-5

Das, B. K., Ellis, A. E., and Collet, B. (2009). Induction and persistence of $\mathrm{Mx}$ protein in tissues, blood and plasma of Atlantic salmon parr, Salmo salar, injected with poly I:C. Fish Shellfish Immunol. 26, 40-48. doi: 10.1016/j.fsi.2008.03.009

De Domenico, I., Zhang, T. Y., Koening, C., Branch, R. W., London, N., Lo, E., et al. (2010). Hepcidin mediates trasncriptional changes that modulate acute cytokine induced inflammatory responses in mice. J. Clin. Invest. 120, 2395-2405. doi: 10.1172/JCI42011 de Kinkelin, P., Bearzotti-Le Berre, M., and Bernard, J. (1980). Viral hemorrhagic septicemia of rainbow trout: selection of a thermoresistant virus variant and comparison of polypeptide synthesis with the wild-type virus strain. J. Virol. 36, 652-658.

de Kinkelin, P., Béarzotti, M., Castric, J., Nougayrède, P., Lecocq-Xhonneux, F., and Thiry, M. (1995). Eighteen years of vaccination against viral haemorrhagic septicaemia in France. Vet. Res. 26, 379-387.

Díaz-Rosales, P., Pereiro, P., Figueras, A., Novoa, B., and Dios, S. (2014). The warm temperature acclimation protein (Wap65) has an important role in the inflammatory response of turbot (Scophthalmus maximus). Fish Shellfish Immunol. 41, 80-92. doi: 10.1016/j.fsi.2014.04.012

Díaz-Rosales, P., Romero, A., Balseiro, P., Dios, S., Novoa, B., and Figueras, A. (2012). Microarray-based identification of differentially expressed genes in families of turbot (Scophthalmus maximus) after infection with viral haemorrhagic septicaemia virus (VHSV). Mar. Biotechnol. 14, 515-529. doi: 10.1007/s10126-012-9465-0

Drakesmith, H., and Prentice, A. (2008). Viral infection and iron metabolism. Nat. Rev. Microbiol. 6, 541-552. doi: 10.1038/nrmicro1930

Duesund, H., Nylund, S., Watanabe, K., Ottem, K. F., and Nylund, A. (2010). Characterization of a VHS virus genotype III isolated from rainbow trout (Oncorhychus mykiss) at a marine site on the west coast of Norway. Virol. J. 7:19. doi: 10.1186/1743-422X-7-19

Dunkelberger, J. R., and Song, W. C. (2010). Complement and its role in innate and adaptive immune responses. Cell Res. 20, 34-50. doi: 10.1038/cr.2009.139

Einer-Jensen, K., Ahrens, P., Forsberg, R., and Lorenzen, N. (2004). Evolution of the fish rhabdovirus viral haemorrhagic septicaemia virus. J. Gen. Virol. 85, 1167-1179. doi: 10.1099/vir.0.79820-0

Einer-Jensen, K., Harmache, A., Biacchesi, S., Bremont, M., Stegmann, A., and Lorenzen, N. (2014). High virulence differences among phylogenetically distinct isolates of the fish rhabdovirus viral hemorrhagic septicaemia virus are not explained by variability of the surface glycoprotein $G$ or the non-virion protein Nv. J. Gen. Virol. 95, 307-316. doi: 10.1099/vir.0.057448-0

Elsayed, E., Faisal, M., Thomas, M., Whelan, G., Batts, W., and Winton, J. (2006). Isolation of viral haemorrhagic septicaemia virus from muskellunge, Esox masquinongy (Mitchill), in Lake St Clair, Michigan, USA reveals a new sublineage of the North American genotype. J. Fish Dis. 29, 611-619. doi: $10.1111 / \mathrm{j} .1365-2761.2006 .00755 . \mathrm{x}$

Estevez, J., Leiro, J., Santamarina, M. T., Dominguez, J., and Ubeira, F. M. (1994). Monoclonal antibodies to turbot (Scophthalmus maximus) immunoglobulins: characterization and applicability in immunoassays. Vet. Immunol. Immunopathol. 41, 353-366. doi: 10.1016/0165-2427(94)90107-4

Evensen, Ø., and Leong, -A. C. (2013). DNA vaccines against viral diseases of farmed fish. Fish Shellfish Immunol. 35, 1751-1758. doi: 10.1016/j.fsi.2013.10.021

Fernandez-Trujillo, A., Ferro, P., Garcia-Rosado, E., Infante, C., Alonso, M. C., Bejar, J., et al. (2008). Poly I:C induces Mx transcription and promotes an antiviral state against sole aquabirnavirus in the flatfish Senegalese sole (Solea senegalensis Kaup). Fish Shellfish Immunol. 24, 279-285. doi: 10.1016/j.fsi.2007.11.008

Figueras, A., Robledo, D., Corvelo, A., Hermida, M., Pereiro, P., Rubiolo, J. A., et al. (2016). Whole genome sequencing of turbot (Scophthalmus maximus; Pleuronectiformes): a fish adapted to demersal life. DNA Res. doi: 10.1093/dnares/dsw007. [Epub ahead of print].

Food and Agriculture Organization of the United Nations (FAO) (2010). The State of World Fisheries and Aquaculture. Rome: FAO.

Fregeneda-Grandes, J. M., and Olesen, N. J. (2007). Detection of rainbow trout antibodies against viral haemorrhagic septicaemia virus (VHSV) by neutralisation test is highly dependent on the virus isolate used. Dis. Aquat. Org. 74, 151-158. doi: 10.3354/dao074151

Gkouvatsos, K., Papanikolaou, G., and Pantopoulos, K. (2012). Regulation of iron transport and the role of transferrin. Biochim. Biophys. Acta 1820, 188-202. doi: 10.1016/j.bbagen.2011.10.013

Harikrishnan, R., Balasundaram, C., and Heo, M. S. (2010). Effect of probiotics enriched diet on Paralichthys olivaceus infected with lymphocystis disease virus (LCDV). Fish Shellfish Immunol. 29, 868-874. doi: 10.1016/j.fsi.2010.07.031

Hastein, T., Hill, B. J., and Winton, J. R. (1999). Successful aquatic animal disease emergency programmes. Rev. Sci. Tech. Off. Int. Epiz. 18, 214-227. doi: 10.20506/rst.18.1.1161 
Hørlyck, V., Mellergård, S., Dalsgaard, I., and Jørgensen, P. E. V. (1984). Occurrence of VHSV in Danish maricultured rainbowtrout. Bull. Eur. Assoc. Fish Pathol. 4, 11-13.

Hugman, A. (2006). Hepcidin: an important new regulator of iron homeostasis. Clin. Lab. Haematol. 28, 75-83. doi: 10.1111/j.1365-2257.2006.00768.x

Iking-Konert, C., Wagner, C., Denefleh, B., Hug, F., Schneider, M., Andrassy, K., et al. (2002). Upregulation of the dendritic cell marker CD83 on polymorphonuclear neutrophils (PMN): divergent expression in acute bacterial infections and chronic inflammatory disease. Clin. Exp. Immunol. 130, 501-508. doi: 10.1046/j.1365-2249.2002.02008.x

Ito, T., Kurita, J., Sano, M., Skall, H. F., Lorenzen, N., Einer-Jensen, K., et al. (2012). Typing of viral hemorrhagic septicemia virus by monoclonal antibodies. J. Gen. Virol. 93, 2546-2557. doi: 10.1099/vir.0.043091-0

Jensen, I., Albuquerque, A., Sommer, A. I., and Robertsen, B. (2002). Effect of poly I:C on the expression of Mx proteins and resistance against infection by infectious salmon anaemia virus in Atlantic salmon. Fish Shellfish Immunol. 13, 311-326. doi: 10.1006/fsim.2001.0406

Jorgensen, J. B., Johansen, L. H., Steiro, K., and Johansen, A. (2003). CpG DNA induces protective antiviral immune responses in Atlantic salmon (Salmo salar L.). J. Virol. 77, 11471-11479. doi: 10.1128/JVI.77.21.11471-11479.2003

Kim, Y. S., Ke, F., and Zhang, Q. Y. (2009). Effect of beta-glucan on activity of antioxidant enzymes and Mx gene expression in virus infected grass carp. Fish Shellfish Immunol. 27, 336-340. doi: 10.1016/j.fsi.2009.06.006

Krause, A., Neitz, S., Mägert, H. J., Schulz, A., Forssmann, W. G., Schulz-Knappe, P., et al. (2000). LEAP-1, a novel highly disulfure-bonded human peptide, exhibits antimicrobial activity. FEBS Lett. 480, 147-150. doi: 10.1016/S00145793(00)01920-7

Kurath, G., and Leong, J. C. (1985). Characterization of infectious hematopoietic necrosis virus mRNA species reveals a nonvirion rhabdovirus protein. J. Virol. 53, 462-468.

LaPatra, S. E., Corbeil, S., Jones, G. R., Shewmaker, W. D., Lorenzen, N., Anderson, E. D., et al. (2001). Protection of rainbow trout against infectious hematopoietic necrosis virus four days after specific or semi-specific DNA vaccination. Vaccine 19, 4011-4019. doi: 10.1016/S0264-410X(01)00113-X

Lecocq-Xhonneux, F., Thiry, M., Dheur, I., Rossius, M., Vanderheijden, N., Martial, J., et al. (1994). A recombinant viral haemorrhagic septicaemia virus glycoprotein expressed in insect cells induces protective immunity in rainbow trout. J. Gen. Virol. 75, 1579-1587. doi: 10.1099/0022-1317-75-7-1579

Lee, M. O., Jang, H. J., Han, J. Y., and Womack, J. E. (2014). Chicken NKlysin is an alpha-helical cationic peptide that exerts its antibacterial activity through damage of bacterial cell membranes. Poult Sci. 93, 864-870. doi: 10.3382/ps.2013-03670

Leong, J. C., and Fryer, J. L. (1993). Viral vaccines for aquaculture. Annu. Rev. Fish Dis. 3, 225-240. doi: 10.1016/0959-8030(93)90036-B

Liang, X., Lin, T., Sun, G., Beasley-Topliffe, L., Cavaillon, J. M., and Warren, H. S. (2009). Hemopexin down-regulates LPS-induced proinflammatory cytokines from macrophages. J. Leukoc. Biol. 86, 229-235. doi: 10.1189/jlb.1208742

Liu, C. H., Chiu, C. H., Wang, S. W., and Cheng, W. (2012). Dietary administration of the probiotic, Bacillus subtilis E20, enhances the growth, innate immune responses, and disease resistance of the grouper, Epinephelus coioides. Fish Shellfish Immunol. 33, 699-706. doi: 10.1016/j.fsi.2012.06.012

Lockhart, K., Bowden, T. J., and Ellis, and, A. E. (2004). Poly I:C-induced Mx responses in Atlantic salmon parr, post-smolts and growers. Fish Shellfish Immunol. 17, 245-254. doi: 10.1016/j.fsi.2004.03.008

López-Muñoz, A., Roca, F. J., Meseguer, J., and Mulero, V. (2009). New insights into the evolution of IFNs: zebrafish group II IFNs induce a rapid and transient expression of IFN-dependent genes and display powerful antiviral activities. J. Immunol. 182, 3440-3449. doi: 10.4049/jimmunol.0802528

Lorenzen, E., Einer-Jensen, K., Martinussen, T., LaPatra, S. E., and Lorenzen, N. (2000). DNA vaccination of rainbow trout against viral hemorrhagic septicemia virus: a dose-response and time-course study. J. Aquat. Anim. Health 12, 167-180. doi: 10.1577/1548-8667(2000)012<0167

Lorenzen, E., Lorenzen, N., Einer-Jensen, K., Brudeseth, B., and Evensen, O. (2005). Time course study of in situ expression of antigens following DNAvaccination against VHS in rainbow trout (Oncorhynchus mykiss Walbaum) fry. Fish Shellfish Immunol. 19, 27-41. doi: 10.1016/j.fsi.2004.10.009

Lorenzen, N., and LaPatra, S. E. (2005). DNA vaccines for aquacultured fish. Rev. Sci. Tech. Off. Int. Epiz. 24, 201-213. doi: 10.20506/rst.24.1.1565
Lorenzen, N., Lorenzen, E., Einer-Jensen, K., Heppell, J., Wu, T., and Davis, H. (1998). Protective immunity to VHS in rainbow trout (Oncorhynchus mykiss, Walbaum) following DNA vaccination. Fish Shellfish Immunol. 8, 261-270. doi: 10.1006/fsim.1997.0134

Lorenzen, N., Olesen, N. J., and Jorgensen, P. E. V. (1990). Neutralization of Egtved virus pathogenicity to cell cultures and fish by monoclonal antibodies to the viral G protein. J. Gen. Virol. 71, 561-567. doi: 10.1099/0022-131771-3-561

Lorenzen, N., Olesen, N. J., and Jorgensen, P. E. V. (1993). Antibody response to VHS virus proteins in rainbow trout. Fish Shellfish Immunol. 3, 461-473. doi: 10.1006/fsim.1993.1045

Lutfalla, G., Crollius, H. R., Stange-Thomann, N., Jaillon, O., Mogensen, K., and Monneron, D. (2003). Comparative genomic analysis reveals independent expansion of a lineage-specific gene family in vertebrates: the class II cytokine receptors and their ligands in mammals and fish. BMC Genomics 4:29. doi: 10.1186/1471-2164-4-29

Ma, D., Ma, A., Huang, Z., Wang, G., Wang, T., Xia, D., et al. (2016). Transcriptome analysis for identification of genes related to gonad differentiation, growth, immune response and marker discovery in the turbot (Scophthalmus maximus). PLoS ONE 11:e0149414. doi: 10.1371/journal.pone.0149414

Magnadottir, B. (2010). Immunological control of fish diseases. Mar. Biotechnol. 12, 361-379. doi: 10.1007/s10126-010-9279-x

Martinez-Lopez, A., García-Valtanen, P., Ortega-Villaizan, M. D. M., Chico, V., Medina-Gali, R. M., Perez, L., et al. (2013). Increasing versatility of the DNA vaccines through modification of the subcellular location of plasmid-encoded antigen expression in the in vivo transfected cells. PLoS ONE 8:e77426. doi: 10.1371/journal.pone.0077426

Mogensen, S. C. (1979). Role of macrophages in natural resistance to virus infections. Microbiol. Rev. 43, 1-26.

Mohan, M., Nair, S., Bhagwat, A., Krishna, T. G., Yano, M., Bhatia, C. R., et al. (1997). Genome mapping, molecular markers and marker-assisted selection in crop plants. Mol. Breed. 3, 87-103. doi: 10.1023/A:1009651919792

Murray, P. J., and Wynn, T. A. (2011). Protective and pathogenic functions of macrophage subsets. Nat. Rev. Immunol. 11, 723-737. doi: 10.1038/nri3073

Nielsen, J. G. (1986). "Scophtalmidae," in Fishes of the North-eastern Atlantic and the Mediterranean, eds. P. J. P. Whitehead, M. L. Bauchot, J. C. Hureau, J. Nielsen, and E. Tortonese (Paris: Unesco), 1287-1293.

Olafsen, J. A. (2001). Interactions between fish larvae and bacteria in marine aquaculture. Aquaculture 200, 223-247. doi: 10.1016/S0044-8486(01)00702-5

Pereiro, P., Balseiro, P., Romero, A., Dios, S., Forn-Cuni, G., Fuste, B., et al. (2012a). High-throughput sequence analysis of turbot (Scophthalmus maximus) transcriptome using 454-pyrosequencing for the discovery of antiviral immune genes. PLoS ONE 7:e35369. doi: 10.1371/journal.pone.0035369

Pereiro, P., Costa, M. M., Díaz-Rosales, P., Dios, S., Figueras, A., and Novoa, B. (2014a). The first characterization of two type I interferons in turbot (Scophthalmus maximus) reveals their differential role, expression pattern and gene induction. Dev. Comp. Immunol. 45, 233-244. doi: 10.1016/j.dci.2014.03.006

Pereiro, P., Dios, S., Boltaña, S., Coll, J., Estepa, A., Mackenzie, S., et al. (2014b). Transcriptome profiles associated to VHSV infection or DNA vaccination in turbot (Scophthalmus maximus). PLOS ONE 9:e104509. doi: 10.1371/journal.pone.0104509

Pereiro, P., Figueras, A., and Novoa, B. (2012b). A novel hepcidin-like in turbot (Scophthalmus maximus L.) highly expressed after pathogen challenge but not after iron overload. Fish Shellfish Immunol. 32, 879-889. doi: 10.1016/j.fsi.2012.02.016

Pereiro, P., Martinez-Lopez, A., Falco, A., Dios, S., Figueras, A., Coll, J. M., et al. (2012c). Protection and antibody response induced by intramuscular DNA vaccine encoding for viral haemorrhagic septicaemia virus (VHSV) G glycoprotein in turbot (Scophthalmus maximus). Fish Shellfish Immunol. 32, 1088-1094. doi: 10.1016/j.fsi.2012.03.004

Pereiro, P., Varela, M., Díaz-Rosales, P., Romero, A., Dios, S., Figueras, A., et al. (2015). Zebrafish Nk-lysins: first insights about their cellular and functional diversification. Dev. Comp. Immunol. 51, 148-159. doi: 10.1016/j.dci.2015.03.009

Rajanbabu, V., Pan, C. Y., Lee, S. C., Lin, W. J., Lin, C. C., and Li, C. L. (2010). Tilapia hepcidin 2-3 peptide modulates lipopolysaccharide-induced 
cytokines and inhibits tumor necrosis factor-alpha through cyclooxygenase2 and phosphodiesterase 4D. J. Biol. Chem. 285, 30577-30586. doi: 10.1074/jbc.M110.137935

Ribas, L., Pardo, B. G., Fernández, C., Álvarez-Dios, J. A., Gómez-Tato, A., Quiroga, M. I., et al. (2013). A combined strategy involving Sanger and 454 pyrosequencing increases genomic resources to aid in the management of reproduction, disease control and genetic selection in the turbot (Scophthalmus maximus). BMC Genomics 14:180. doi: 10.1186/1471-2164-14-180

Robertsen, B., Bergan, V., Rokenes, T., Larsen, R., and Albuquerque, A. (2003). Atlantic salmon interferon genes: cloning, sequence analysis, expression, and biological activity. J. Interferon Cytokine Res. 23, 601-612. doi: $10.1089 / 107999003322485107$

Rodríguez-Ramilo, S. T., De La Herrán, R., Ruiz-Rejón, C., Hermida, M., Fernández, C., Pereiro, P., et al. (2014). Identification of quantitative trait loci associated with resistance to viral haemorrhagic septicaemia (VHS) in turbot (Scophthalmus maximus): a comparison between bacterium, parasite and virus diseases. Mar. Biotechnol. 16, 265-276. doi: 10.1007/s10126-013-9544-X

Rodríguez-Ramilo, S. T., Fernández, J., Toro, M. A., Bouza, C., Hermida, M., Fernández, C., et al. (2013). Uncovering QTL for resistance and survival time to Philasterides dicentrarchi in turbot (Scophthalmus maximus). Anim. Genet. 44, 149-157. doi: 10.1111/j.1365-2052.2012.02385.x

Rodríguez-Ramilo, S. T., Toro, M. A., Bouza, C., Hermida, M., Pardo, B. G., Cabaleiro, S., et al. (2011). QTL detection for Aeromonas salmonicida resistance related traits in turbot (Scophthalmus maximus). BMC Genomics 12:541. doi: 10.1186/1471-2164-12-541

Ross, K., McCarthy, U., Huntly, P. J., Wood, B. P., Stuart, D., Rough, E. I., et al. (1994). An outbreak of viral haemorrhagic septicaemia (VHS) in turbot (Scophthalmus maximus) in Scotland. Bull. Eur. Assoc. Fish Pathol. 14, 213-214.

Sadler, A. J., and Williams, B. R. G. (2008). Interferon-inducible antiviral effectors. Nat. Rev. Immunol. 8, 559-568. doi: 10.1038/nri2314

Schlotfeldt, H. J., Ahne, W., Vestergård-Jørgensen, P. E., and Glende, W. (1991). Occurrence of viral haemorrhagic septicaemia virus in turbot (Scophthalmus maximus) - a natural outbreak. Bull. Eur. Assoc. Fish Pathol. 11, 105-107.

Schönherz, A. A., Lorenzen, N., and Einer-Jensen, K. (2013). Inter-species transmission of viral hemorrhagic septicemia virus (VHSV) from turbot (Scophthalmus maximus) to rainbow trout (Oncorhynchus mykiss). J. Gen. Virol. 94, 869-875. doi: 10.1099/vir.0.048223-0

Schutze, H., Mundt, E., and Mettenleiter, T. C. (1999). Complete genomic sequence of viral hemorrhagic septicemia virus, a fish rhabdovirus. Virus Genes 19, 59-65. doi: 10.1023/A:1008140707132

Skall, H. F., Olesen, N. J., and Mellergaard, S. (2005). Viral haemorrhagic septicaemia virus in marine fish and its implications for fish farming-a review. J. Fish Dis. 28, 509-529. doi: 10.1111/j.1365-2761.2005.00654.x

Smith, L. C., Barela Hudgell, M. A., Deiss, T., Golconda, P., Krasnec, K., Lun, C. M., et al. (2016). Conference report: the 13th congress of the international society of developmental and comparative immunology. Dev. Comp. Immunol. 55, 56-64. doi: 10.1016/j.dci.2015.10.006

Snow, M., Bain, N., Black, J., Taupin, V., Cunningham, C. O., King, J. A., et al. (2004). Genetic population structure of marine viral haemorrhagic septicaemia virus (VHSV). Dis. Aquat. Org. 61, 11-21. doi: 10.3354/dao061011

Snow, M., Cunningham, C. O., Melvin, W. T., and Kurath, G. (1999). Analysis of the nucleoprotein identifies distinct lineages of viral haemorrhagic septicaemia virus within the European marine environment. Virus Res. 63, 35-44. doi: 10.1016/S0168-1702(99)00056-8

Snow, M., King, J. A., Garden, A., Shanks, A. M., and Raynard, R. S. (2005). Comparative susceptibility of turbot Scophthalmus maximus to different genotypes of viral haemorrhagic septicaemia virus. Dis. Aquat. Org. 67, 31-38. doi: 10.3354/dao067031

Snow, M., and Smail, D. A. (1999). Experimental susceptibility of turbot Scophthalmus maximus to viral haemorrhagic septicaemia virus isolated from cultivated turbot. Dis. Aquat. Org. 38, 163-168. doi: 10.3354/dao038163

Son, V. M., Chang, C. C., Wu, M. C., Guu, Y. K., Chiu, C. H., and Cheng, W. (2009). Dietary administration of the probiotic, Lactobacillus plantarum, enhanced the growth, innate immune responses, and disease resistance of the grouper Epinephelus coioides. Fish Shellfish Immunol. 26, 691-698. doi: 10.1016/j.fsi.2009.02.018

Spiller, F., Costa, C., Souto, F. O., Vinchi, F., Mestriner, F. L., Laure, H. J., et al. (2011). Inhibition of neutrophil migration by hemopexin leads to increased mortality due to sepsis in mice. Am. J. Respir. Crit. Care Med. 183, 922-931. doi: $10.1164 / \mathrm{rccm} .201002-0223 \mathrm{OC}$
Stenger, S., Hanson, D. A., Teitelbaum, R., Dewan, P., Niazi, K. R., Froelich, C. J., et al. (1998). An antimicrobial activity of cytolytic T cells mediated by granulysin. Science 282, 121-125. doi: 10.1126/science.282.5386.121

Tafalla, C., Figueras, A., and Novoa, B. (1998). In vitro interaction of viral haemorrhagic septicaemia virus and leukocytes from trout (Oncorhynchus mykiss) and turbot (Scophthalmus maximus). Vet. Immunol. Immunopathol. 62, 359-366. doi: 10.1016/S0165-2427(97)00167-0

Tafalla, C., Figueras, A., and Novoa, B. (1999). Role of nitric oxide on the replication of viral haemorrhagic septicemia virus (VHSV), a fish rhabdovirus. Vet. Immunol. Immunopathol. 72, 249-256. doi: 10.1016/S01652427(99)00109-9

Tafalla, C., Figueras, A., and Novoa, B. (2001). Viral hemorrhagic septicemia virus alters turbot Scophthalmus maximus macrophage nitric oxide production. Dis. Aquat. Org. 47, 101-107. doi: 10.3354/dao047101

Tolosano, E., Fagoonee, S., Morello, N., Vinchi, F., and Fiorito, V. (2010). Heme scavenging and the other facets of hemopexin. Antioxid. Redox Signal. 12, 305-320. doi: 10.1089/ars.2009.2787

Tordo, N., Benmansour, A., Calisher, C., Dietzgen, R. G., Fang, R. X., Jackson, A. O., et al. (2005). "Rhabdoviridae," in Virus Taxonomy. Eighth Report of the International Committee on Taxonomy of Viruses, eds C. M. Fauquet, M. A. Mayo, J. Maniloff, U. Desselberger, L. A. Ball (London, UK: Elsevier Academic Press), 623-644.

Trapani, J. A., and Smyth, M. J. (2002). Functional significance of the perforin/granzyme cell death pathway. Nat. Rev. Immunol. 2, 735-747. doi: $10.1038 /$ nri911

Varela, M., Díaz-Rosales, P., Pereiro, P., Forn-Cuní, G., Costa, M. M., Dios, S., et al. (2014a). Interferon-induced genes of the expanded IFIT family show conserved antiviral activities in non-mammalian species. PLoS ONE 9:e100015. doi: 10.1371/journal.pone.0100015

Varela, M., Romero, A., Dios, S., van der Vaart, M., Figueras, A., Meijer, A. H., et al. (2014b). Cellular visualization of macrophage pyroptosis and interleukin$1 \beta$ release in a viral hemorrhagic infection in zebrafish larvae. J. Virol. 88, 12026-12040. doi: 10.1128/JVI.02056-14

Walker, P. J., Benmansour, A., Dietzgen, R., Fang, R. X., Jackson, A. O., Kurath, G., et al. (2000). "Family Rhabdoviridae," in Virus Taxonomy: Classification and Nomenclature of Viruses. Seventh Report of the International Committee on Taxonomy of Viruses, eds M. H. V. van Regenmortel, C. M. Fauquet, D. H. L. Bishop, E. B. Carstens, M. K. Estes, S. M. Lemon, J. Maniloff, M. A. Mayo, D. J. McGeoch, C. R. Pringle, and R. B. Wickner (San Diego, CA: Academic Press), 563-583.

Winton, J. R. (1997). Immunization with viral antigens: infectious haematopoietic necrosis. Dev. Biol. Stand. 90, 211-220.

Wolf, K. (1988). "Viral hemorrhagic septicemia," in Fish Viruses and Fish Viral Diseases, ed K. Wolf (Ithaca, NY: Cornell University Press), 217-249.

Zhang, M., Li, M. F., and Sun, L. (2014). NKLP27: a teleost NK-lysin peptide that modulates immune response, induces degradation of bacterial DNA, and inhibits bacterial and viral infection. PLOS ONE 9:e106543. doi: 10.1371/journal.pone.0106543

Zhang, M., Long, H., and Sun, L. (2013). A NK-lysin from Cynoglossus semilaevis enhances antimicrobial defense against bacterial and viral pathogens. Dev. Comp. Immunol. 40, 258-265. doi: 10.1016/j.dci.2013.03.005

Zhou, L. J., and Tedder, T. F. (1996). CD14+ blood monocytes can differentiate into functionally mature CD $83+$ dendritic cells. Proc. Natl. Acad. Sci. U.S.A. 93, 2588-2592. doi: 10.1073/pnas.93.6.2588

Zou, J., and Secombes, C. J. (2011). Teleost fish interferons and their role in immunity. Dev. Comp. Immunol. 35, 1376-1387. doi: 10.1016/j.dci.2011.07.001

Zou, J., Tafalla, C., Truckle, J., and Secombes, C. J. (2007). Identification of a second group of type I IFNs in fish sheds light on IFN evolution in vertebrates. J. Immunol. 179, 3859-3871. doi: 10.4049/jimmunol.179.6.3859

Conflict of Interest Statement: The authors declare that the research was conducted in the absence of any commercial or financial relationships that could be construed as a potential conflict of interest.

Copyright (c) 2016 Pereiro, Figueras and Novoa. This is an open-access article distributed under the terms of the Creative Commons Attribution License (CC BY). The use, distribution or reproduction in other forums is permitted, provided the original author(s) or licensor are credited and that the original publication in this journal is cited, in accordance with accepted academic practice. No use, distribution or reproduction is permitted which does not comply with these terms. 